\title{
Use of Tithonia diversifolia (hemsl.) A. Gray in the diet of growing lambs
}

[Uso de tithonia diversifolia (hemsl.) A. Gray na dieta de cordeiros em crescimento]

\author{
S. Cadena-Villegas ${ }^{1}$, H.G. Martínez-Maldonado ${ }^{2}$, E. Sosa-Montes ${ }^{2}$, S.I. Mendoza-Pedroza ${ }^{3}$, \\ T. Salinas-Rios ${ }^{4}$, E.J. Flores-Santiago ${ }^{5}$, J.I. Alejos de la Fuente ${ }^{2 *}$
}

\author{
${ }^{1}$ Postgraduate College - Campus Tabasco - Master of Science in Agri-Food Production in \\ the Tropic. H. Cárdenas, Tabasco. México \\ ${ }^{2}$ Chapingo Autonomous University, Zootecnichs Departament - Texcoco, México \\ ${ }^{3}$ Postgraduate College - Campus Montecillos - Program of Genetic Resources \\ and Productivity - Livestock- Texcoco, México \\ ${ }^{4}$ Faculty of Veterinary Medicine and Zootechnics - Benito Juárez de \\ Oaxaca Autonomous University - Oaxaca, México \\ ${ }^{5}$ Chapingo Autonomous University. South-southeast Regional University Unit, km 7.5. \\ Teapa- Vicente Guerrero highway. Teapa, Tabasco. México
}

\begin{abstract}
Two assays were conducted to study the Tithonia diversifolia (Td) plant: (1) chemical analysis and in vitro dry matter digestibility (IVDMD) of plant parts and (2) productive performance of lambs fed a traditional diet or a Td diet (30\% of Td plus 70\% of the traditional diet). The plant parts studied were leaves (L), leaves and petioles (LP); and leaves, petioles and stems (LPS). Feed intake, weight gain and feed conversion were registered weekly during five weeks of experimentation. The $\mathrm{L}$ showed higher $(\mathrm{P}<0.05)$ crude protein content (26.7\%) than LP and LPS (25.5 and 19.7\%, respectively). Crude fiber (11.2\%), neutral detergent fiber $(45.4 \%)$, cellulose $(16.9 \%)$ and hemicellulose $(33.5 \%)$ were lower in L than in LP (12.5, 46.7, 18.0 and $35.7 \%$, respectively) and LPS (22.6, 59.2, 27.0 and 43.5\%, respectively). The L and LP showed the highest IVDMD (89.2 and $88.2 \%$, respectively vs. $77.2 \%$ of LPS). The Td diet resulted in greater feed intake and weight gain and lower feed conversion than the traditional diet. Therefore, Tithonia diversifolia is a forage plant of good quality for lambs which does not affect the productive performance.
\end{abstract}

Keywords: digestibility, feed intake, weight gain, feed conversion, lambs

\section{RESUMO}

Dois ensaios foram realizados para estudar a planta de Tithonia diversifolia (Td): (1) análise química e digestibilidade in vitro da matéria seca (DIVMS) de partes de plantas e (2) desempenho produtivo de cordeiros alimentados com dieta tradicional ou dieta Td (30\% de Td mais $70 \%$ da dieta tradicional). As partes vegetais estudadas foram folhas (L), folhas e pecíolos (LP); folhas, pecíolos e caules (LPS). $O$ consumo de ração, o ganho de peso e a conversão alimentar foram registrados semanalmente, durante cinco semanas de experimentação. $O$ L apresentou maior $(P<0,05)$ conteúdo de proteína bruta $(26,7 \%)$ que o LP e o LPS (25,5 e 19,7\%, respectivamente). Fibra bruta (11,2\%), fibra em detergente neutro $(45,4 \%)$, celulose (16,9\%) e hemicelulose (33,5\%) foram menores em $L$ do que em $L P(12,5,46,7,18,0$ e $35,7 \%$, respectivamente) e LPS $(22,6,59,2,27,0$ e 43,5\%, respectivamente). O L e o LP apresentaram o maior DIVMS (89,2 e 88,2\%, respectivamente vs. $77,2 \%$ do LPS). A dieta Td resultou em maior consumo de ração e maior ganho de peso e menor conversão alimentar que a dieta tradicional. Portanto, Tithonia diversifolia é uma planta forrageira de boa qualidade para cordeiros que não afeta o desempenho produtivo.

Palavras-chave: digestibilidade, consumo de ração, ganho de peso, conversão alimentar, cordeiros

Recebido em 12 de fevereiro de 2020

Aceito em 22 de junho de 2020

*Autor para correspondência (corresponding author)

E-mail: jalejosd@chapingo.mx 


\section{INTRODUCTION}

In Mexico, sheep production is an important activity, given that from 2000 to 2014 , the sheep inventory increased by $28.9 \%$, from 6.0 to 8.5 million animals (Hernández-Marín et al., 2017). The extensive system that predominates with this activity has not been fully exploited, and farmers focus on concentrate supplements to improve production with the corresponding increase in costs and decrease in profits (Espinosa-García et al., 2015). In tropical areas, farmers also feed their lambs with concentrate supplements based on cereal grains and protein ingredients of high cost and low availability (Vázquez-Mendoza et al., 2012). This situation creates the need to implement feeding strategies based on forages that allow improving the productive performance of sheep in the tropics.

These forages must preferably contain between $14 \%$ and $18 \%$ crude protein and be available throughout the year (Vázquez-Mendoza et al., 2012). One of these forages could be Tithonia diversifolia (Hemsl.) A.gray (Td), a native shrub that reaches between 1.5 to $4.0 \mathrm{~m}$ height (González-Castillo et al., 2014). This plant has a large annual biomass production, between 30 and 70 tha $^{-1}$ as green forage; it requires little handling for its cultivation, it is fast-growing and up to $33 \%$ crude protein accumulates in its leaves (Ruíz et al., 2014). The chemical composition of $\mathrm{Td}$ depends on the environment (Rodríguez et al., 2008), therefore a chemical evaluation of this plant prior to its use as forage is advisable.

Ekeocha and Fakolade (2012) used this plant for ewes at up to $30 \%$ of the diet. Fasuyi and Ibitayo (2011) reported the presence of essential amino acids in Td based diets, particularly isoleucine, leucine and lysine and other aromatic amino acids such as phenylalanine and valine. Until today, the use of $\mathrm{Td}$ as forage for lambs has been scantly investigated, therefore, the objective of the present study was to evaluate the nutritional value of the morphological parts of Tithonia diversifolia, and the productive performance of lambs fed this plant at $30 \%$ of the diet.

\section{MATERIALS AND METHODS}

The animals were managed according to the technical specifications for the production, care and use of laboratory animals NOM-062-ZOO1999. The forage samples were collected in Hueytamalco, Puebla, Mexico, at 97 16'37.2" W and $20^{\circ} 02^{\prime} 12.3^{\prime \prime} \mathrm{N}$ and $446 \mathrm{~m}$ altitude. The mean monthly temperature ranges from 16 to $26^{\circ} \mathrm{C}$, and the mean annual rainfall fluctuates between 1,500 y 3,600 $\mathrm{mm}$; the rainy season occurs from June to November and during part of the winter; the soil type is mainly Regosol (INEGI, 2009). The forage collection was carried out in July during rainy season while forage was in pre-flowering phenological stage.

Tithonia diversifolia (Hemsl. A.gray) plants, which are considered undesirable, were collected over a two hectare area of agricultural land. $T d$ harvest took place in pre-flowering stage, 60 days after previous cutting to obtain the greatest amount of biomass from the plants. The plants were randomly sampled and cut at 1 mhigh from the soil surface. A total amount of $100 \mathrm{~kg}$ of plants was collected. Subsequently, in order to obtain a gradient of protein concentration, plants were separated into their above ground morphological parts: leaves (L), leaves and petioles (LP); and leaves, petioles and stems (LPS). After being sundried, the samples were placed in paper bags and dried in a forced-air oven at $55^{\circ} \mathrm{C}$ for $72 \mathrm{~h}$; the dried material was ground throughout a $2 \mathrm{~mm}$ mesh.

The percentage of moisture, ether extract (EE), crude fiber $(\mathrm{CF})$, crude protein (PC), ash, neutral detergent fiber (NDF), acid detergent fiber (ADF), lignin, silica and IVDMD (in vitro dry matter digestibility, 72 hours of incubation time), were determined according to the AOAC (2000) official methodology. The experimental work was carried out in the sheep facilities of the Experimental Farm of the Animal Husbandry Department, Chapingo Autonomous University, located in Mexico at 98 $52^{\prime} 15.36^{\prime}$ ' W and $19^{\circ} 29^{\prime} 43.34^{\prime}, \mathrm{N}$, and $2250 \mathrm{~m}$ altitude. The climate is temperate subhumid with rains in summer, the average annual temperature is 15.2 ${ }^{\circ} \mathrm{C}$ and the average annual rainfall is $664.8 \mathrm{~mm}$ (García, 2004).

Twenty lambs of the Rideau Arcott breed (initial body weight between 22 and $30 \mathrm{~kg}$ ) were housed 
in individual pens. The lambs were randomly distributed to one of two diets: (1) control or traditional diet $=70 \%$ concentrate plus $30 \%$ corn silage and (2) Td diet $=70 \%$ control diet plus $30 \%$ Td meal of complete plants (aboveground parts or LPS). The LPS fraction was used to include as much biomass as possible and it was determined that it was feasible to use this forage fraction due to its protein content. Voluntary food consumption is considered to be $3.5 \%$ of the live weight.

This percentage was divided by three, which results in $1.16 \%$, and it was determined that this represents $33.14 \%$ of the ration. Upon rounding this figure, it was determined that $30 \%$ inclusion would be a good starting parameter. Therefore, the percentage of inclusion of the concentrated feed in the ration of fattening lambs was $80 \%$ concentrated feed and $20 \%$ corn silage, while Td diet consisted of $56 \%$ concentrated feed, $14 \%$ corn silage and $30 \% \mathrm{Td}$ flour. The concentrate was the one normally prepared at the farm for intensive lamb production: $15 \%$ crude protein, minimum; $4 \%$ crude fat, minimum; $8 \%$ crude fiber, maximum; $8 \%$ ash, maximum and $12 \%$ moisture, maximum.
7 days before the start of the experiment, the lambs were submitted to preventive medicine treatment, where vitamins $\mathrm{A}, \mathrm{D}$ and $\mathrm{E}(2 \mathrm{~mL}$ per lamb of Vigantol®, Bayer, Mexico mixed with $2 \mathrm{~mL}$ sterilized water) were applied orally, and an antiparasitic medication (5 $\mathrm{mg}$ of ivermectin and $125 \mathrm{mg}$ of closantel per $25 \mathrm{~kg}$ of body weight) was injected subcutaneously. Feed intake was determined daily in the mornings, by weight difference of feed offered and rejected. Weekly body weight of animals was used to estimate daily weight gain and feed conversion. All data were analyzed with the PROC GLM SAS ${ }^{\circledR}$ procedure (SAS, 2012). The comparison of means was carried out using the Tukey test at $\mathrm{P} \leq 0.05$.

\section{RESULTS AND DISCUSSION}

Table 1 and 2 show the results of chemical analyses. In general, as expected, crude protein was higher $(\mathrm{P} \leq 0.05)$ in $\mathrm{L}$ and LP than in LPS. However, crude fiber, neutral detergent fiber, acid detergent fiber, cellulose, hemicellulose and lignin were lower $(\mathrm{P} \leq 0.05)$ in $\mathrm{L}$ and LP than in LPS. Therefore, while the nutritional values of leaves and petioles are similar, together they are better than the value of the stem.

Table 1. Ether extract, crude protein, ash and silica of Tithonia diversifolia (aboveground parts, \% dry basis)

\begin{tabular}{lcccc} 
& \multicolumn{4}{c}{ Aboveground part } \\
& $\mathrm{L}$ & LP & LPS & SEM \\
\hline $\mathrm{EE}$ & $3.71 \pm 0.16$ & $3.47 \pm 0.11$ & $2.40 \pm 0.19$ & 5.36 \\
$\mathrm{CP}$ & $26.72 \pm 0.62^{\mathrm{a}}$ & $25.25 \pm 0.37^{\mathrm{b}}$ & $19.04 \pm 0.92^{\mathrm{c}}$ & 2.68 \\
$\mathrm{Ash}$ & $13.05 \pm 1.36$ & $14.66 \pm 1.47$ & $13.01 \pm 1.38$ & 3.85 \\
$\mathrm{Si}$ & $1.25 \pm 0.1$ & $0.91 \pm 0.01$ & $0.99 \pm 0.01$ & 1.72 \\
\hline
\end{tabular}

EE: ether extract, CP: crude protein, Si: silica, L: leaves, LP: leaves and petioles, LPS: leaves, petioles and stem, SEM: standard error of mean. $\mathrm{a}, \mathrm{b}, \mathrm{c}$ Values in the same row with different superscript are statistically different $(\mathrm{P} \leq 0.05)$. Although LPS presents the lowest value, the LPS samples (aboveground part of Tithonia diversifolia or $\mathrm{Td}$ ), showed a good level of $\mathrm{CP}$ content for sheep (19\%). The CP values of LPS observed in this study were similar to those reported by La et al. (2012) who studied $9 \mathrm{Td}$ ecotypes ranging from 18.3 to $26.4 \% \mathrm{CP}$ content. Likewise, Gutiérrez et al. (2014) reported a value of $16.5 \% \mathrm{CP}$, lower than the value of LPS determined in the present assay. Lezcano et al. (2012) reported that leaf and tender stems contain low CF content, however, as time passes $\mathrm{CF}$ increases in the stems, while in the leaf $\mathrm{CF}$ remains unchanged.

Verdecia et al. (2011) observed NDF values between 43.6 and $50.5 \%$ at different cutting intervals; while Gallego et al. (2017) observed a percentage of NDF similar to that of the present study $(53.81 \%)$. In contrast, Naranjo and Cuartas (2011) when measuring NDF in leaf and petiole samples of Tithonia diversifolia, obtained a lower percentage $(38.62 \%)$ than that observed in this investigation $(46.7 \%)$. The ADF values of the present study $(12.0,11.0$ and $15.8 \%$ for L, LP and LPS, respectively) were lower than those reported by Verdecia et al. (2011), Meza et al. (2014) and Gallego et al. (2017) who reported values in the range of 30.0 to $48.5 \%$. Odedire and Oloidi (2014) reported that during the dry season in Nigeria, 
non-cultivated Tithonia diversifolia harvested before flowering presented $21.1 \% \mathrm{CP}, 18.9 \%$ crude fiber, $14.1 \%$ ash, $43.2 \% \mathrm{ADF}, 63.2 \% \mathrm{NDF}$, $20.0 \%$ hemicellulose and $3.7 \%$ lignin.

With the exclusion of ADF, hemicellulose and lignin, the other values reported by these authors were similar to those observed with LPS in the present study. In general, some variation was observed when the nutritive values of Tithonia diversifolia, reported in the literature were compared with those found in the present study. Hence, the importance of determining the nutritive content of this plant, mainly at the regional level and possibly at different cutting intervals. All the samples had high digestibility (Table 2), L and LP recorded values of $89.2 \%$ and $88.2 \%$, respectively, which were higher $(\mathrm{P}<0.05)$ than that of the LPS sample (77.2\%).

Table 2. The IVDMD and fiber components of Tithonia diversifolia (aboveground parts, $\%$ dry basis)

\begin{tabular}{lcccc}
\hline \multicolumn{4}{c}{ Aboveground part } \\
IVDMD & $\mathrm{L}$ & LP & LPS & SEM \\
CF & $89.24^{\mathrm{a}}$ & $88.16^{\mathrm{a}}$ & $77.19^{\mathrm{b}}$ & 5.36 \\
$\mathrm{NDF}$ & $11.19^{\mathrm{b}}$ & $12.46^{\mathrm{b}}$ & $22.57^{\mathrm{a}}$ & 2.68 \\
ADF & $45.42^{\mathrm{b}}$ & $46.74^{\mathrm{b}}$ & $59.22^{\mathrm{a}}$ & 3.85 \\
Cellulose & $11.95^{\mathrm{b}}$ & $11.01^{\mathrm{b}}$ & $15.76^{\mathrm{a}}$ & 1.72 \\
Hemicellulose & $16.86^{\mathrm{b}}$ & $17.95^{\mathrm{b}}$ & $27.00^{\mathrm{a}}$ & 3.47 \\
Lignin & $33.47^{\mathrm{b}}$ & $35.72^{\mathrm{b}}$ & $43.45^{\mathrm{a}}$ & 3.91 \\
\hline
\end{tabular}

IVDMD: in vitro dry matter digestibility, CF: crude fiber, NDF: neutral detergent fiber, ADF: acid detergent fiber, L: leaves, LP: leaves and petioles, LPS: leaves, petioles and stems. SEM: standard error of mean. ${ }^{a}$ b, ${ }^{c}$ Values in the same column with different superscript are statistically different $(\mathrm{P} \leq 0.05)$.

Soto and Reinoso (2007) found 57\% IVDMD of Tithonia diversifolia $(T d)$ at 10 weeks of cutting interval. When studying a diet for rabbits with 9 and $18 \%$ of $T d$, Nieves et al. (2011), reported values of 53.5 and $51.3 \%$ IVDMD, respectively. However, in agreement with the present study, La et al. (2012) reported that the IVDMD of this forage is in the range of 72.3 to $79.8 \%$, while the in vivo digestibility varies in the range of 81.1 to $85.7 \%$. In this sense, the high digestibility of $\mathrm{Td}$ probably allows good absorption of nutrients in the rumen, as well as a greater contribution of energy for the ruminant, and consequently, it is possible to have favorable animal behavior if $\mathrm{Td}$ is included in the diet of lambs.

In the first week of the experimental period, lambs fed the traditional diet had $(\mathrm{P} \leq 0.05)$ higher feed intake (FI) than those with the Td diet. In the other weeks, no differences $(\mathrm{P}>0.05)$ in FI were observed between diets (Table 3 ). To this respect, Costa et al. (2018) while investigating the requirements of energy and protein for weight gain and carcass quality of lambs (Santa Inés and Morada Nova, 28 to $31 \mathrm{~kg} \mathrm{BW}$ ), reported a FI of $1 \mathrm{~kg} \mathrm{day}^{-1}$, a value lower than that found in this study (FI>1, for both diets, every week). Furthermore, Ma et al. (2019) evaluating the growth and nutrient utilization of Dorper lambs and their crosses (average initial BW of $28.3 \mathrm{~kg}$ ), found a FI of 1.2 to $1.3 \mathrm{~kg} \mathrm{day}^{-1}$, values similar to those obtained in the present study (Table 3 ).

Forbes (2007) affirmed that the sheep's ability to select among parts of forages is very important to regulate the voluntary FI. Additionally, there exists evidence that feed intake is limited by rumen filling and physiological factors (Forbes, 2007). Fiber limits FI due to rumen filling (Bambi et al., 2011), however, a fully ground and mixed plant as was the case of Tithonia diversifolia, is not easy to select. In this study, the $\mathrm{Td}$ diet produced slightly lower FI per animal than the traditional one (1.13 vs. $1.2 \mathrm{~kg}$ day $^{-1}$, respectively; Table 3 first week). Therefore, the decrease of FI on the first week of experimentation was due to both the filling effect and the physiological factor; that is, more fiber $(22.6 \% \mathrm{CF})$ of the Td diet vs. $8 \% \mathrm{CF}$ of the traditional diet, and new odors and flavors (substances necessarily consumed due to the difficulty of selection) of the Td diet. From the second week of experimentation onwards, the lambs were fully adapted to the new Td diet and FI remained the same between both diets (Table 3).

Despite its low FI, the Td diet resulted in a higher daily weight gain (DWG, $\mathrm{g} \mathrm{day}^{-1}$ ) per animal and 
better feed conversion ( $\mathrm{FC}, \mathrm{g} \mathrm{g}^{-1}$ ) than the traditional diet $\left(240 \mathrm{~g} \mathrm{day}^{-1}\right.$ and $\left.5.8 \mathrm{~g} \mathrm{~g}^{-1}\right)$ on the second week of experimentation (Table 3 ). This highlights the great nutritional value of this plant for lamb feeding. From the third week of experimentation onwards, DWG and FC were the same every week when comparing both diets (Table 3). In an assay on feed efficiency and microbial profile of Suffolk and Rambouillet lambs (heavier than those of the present study), Ellison et al. (2017) reported a daily FI per animal of 2.3 and $3.3 \mathrm{~kg} \mathrm{day}^{-1}$, respectively, values greater than those found in this investigation. Furthermore, when studying an herbaceous plant (Pelegonia) for growing lambs, Christodoulou et al. (2007) reported a FI per animal of 1.6 and 2.0 $\mathrm{kg} \mathrm{day}{ }^{-1}$, values similar to those of the present work. Based on the previous discussion, it is possible to say that the FI of lambs in this study is in the range of the literature values. Therefore, when comparing with the traditional diet, neither FI and DWG nor FC changed by the inclusion of $\mathrm{Td}$ (at the $30 \%$ level) in the diet of the lambs.

Table 3. Daily feed consumption $\left(\mathrm{kg} \mathrm{day}^{-1}\right)$, daily weight gain $\left(\mathrm{g} \mathrm{day}^{-1}\right)$ and feed conversion $\left(\mathrm{g} \mathrm{g}^{-1}\right)$, of lambs fed a diet containing 30\% of Tithonia diversifolia (Hemsl.) A.gray in the diet, all values as dry matter per animal

\begin{tabular}{lccccc} 
& \multicolumn{5}{c}{ Week } \\
& 1 & 2 & 3 & 4 & 5 \\
\hline Traditional diet & $1.2 \pm 0.01^{\mathrm{a}}$ & $1.39 \pm 0.02$ & $1.48 \pm 0.04$ & $1.42 \pm 0.04$ & $1.45 \pm 0.04$ \\
Td diet & $1.13 \pm 0.01^{\mathrm{b}}$ & $1.41 \pm 0.01$ & $1.49 \pm 0.03$ & $1.46 \pm 0.03$ & $1.50 \pm 0.03$ \\
DWG $\left(\mathrm{g} \mathrm{d}^{-1}\right)$ & & & & & \\
Traditional diet & $250 \pm 38$ & $240 \pm 53^{\mathrm{a}}$ & $270 \pm 38$ & $230 \pm 20$ & $270 \pm 20$ \\
Td diet & $310 \pm 41$ & $290 \pm 35^{\mathrm{b}}$ & $280 \pm 40$ & $260 \pm 60$ & $280 \pm 20$ \\
FC $\left(\mathrm{g} \mathrm{g}^{-1}\right)$ & & & & & \\
Traditional diet & $4.59 \pm 0.58$ & $5.79 \pm 0.37^{\mathrm{a}}$ & $5.48 \pm 0.52$ & $5.82 \pm 0.63$ & $5.72 \pm 0.67$ \\
Td diet & $3.82 \pm 0.66$ & $4.82 \pm 0.15^{\mathrm{b}}$ & $5.32 \pm 0.57$ & $5.61 \pm 0.81$ & $5.40 \pm 0.43$ \\
\hline
\end{tabular}

FI: feed intake; DWG: daily weight gain; FC: feed conversion. ${ }^{\mathrm{a}, \mathrm{b}, \mathrm{c}}$ Values for each variable in the same column with different superscript are statistically different $(\mathrm{P} \leq 0.05)$. Traditional diet: control or conventional diet of the farm. Td-diet: diet based on Tithonia diversifolia plant.

Cunha et al. (2013) reported a DWG per animal of $228 \mathrm{~g} \mathrm{day}^{-1}$, of lambs finished in paddock; this value is lower than ours. With respect to this, Sormunen-Cristian (2013) when studying the use of several grains in lamb feeding, reported daily weight gains per animal of 201 to $260 \mathrm{~g} \mathrm{day}^{-1}$ and Rihawi et al. (2010) reported 300 to $322 \mathrm{~g} \mathrm{day}^{-1}$; values similar to those observed in the first two weeks of the present study. These studies corroborate that the use of $\mathrm{Td}$ for the growth of finishing lambs maintains the productive performance and produces similar results to those reported previously.

With the exclusion of the second week, where the Td-diet showed better FC, no differences were observed between diets in the remaining weeks of the study. The FC values observed in the present study were greater ( 3.8 to $5.6 \mathrm{~g} \mathrm{~g} \mathrm{~g}^{-1}$ ) than those reported by Costa et al. (2018) using Santa Inés and Morada Nova lambs (4.3 to $4.8 \mathrm{~g} \mathrm{~g}^{-1}$ ). The weight of these lambs ranged between 25 and 31 $\mathrm{kg}$, very similar to that of the preset study. These authors report that the greater the weight gain, the greater the FC; a similar trend was observed in the present study. The results obtained with FC also indicate (as is the case with FI and DWG) that Tithonia diversifolia meal can be used at the $30 \%$ level as an ingredient in the diet for lambs.

\section{CONCLUSIONS}

The nutritional content of Tithonia diversifolia leaves and petioles are similar, however, they are better than that of the stems. Due to the good content of nutrients and a greater amount of forage of the whole plant, its inclusion is possible, given that it does not affect the weight gain, feed consumption and feed conversion of growing lambs, making it a good option where this resource is available or its cultivation is possible. 


\section{REFERENCES}

AOAC. Official methods of analysis. 17.ed. Arlington: Association of Official Analytical Chemists, 2000.

BAMBI, H.J.; BOSTON, R.C.; MODESTO, R.B.; SCHAER, T.P. Perioperative ruminal $\mathrm{pH}$ changes in domestic sheep (Ovis aries) housed in biomedical research setting. J. Am. Assoc. Lab. Anim. Sci., v.50, p.27-32, 2011.

CHRISTODOULOU, V.; BAMPIDIS, V.A.; SOSSIDOU, E.; AMBROSIADIS, J. Evaluation of Florina (Pelegonia) sheep breed for growth and carcass trait. Small Ruminant Res., v.70, p.239247, 2007.

COSTA, R.G.; LIMA, H.B.; MEDEIROS, A.N. et al. Net protein and energy requirements for weight gain of Santa Inês and Morada Nova sheep. Livest. Sci., v.214, p.288-292, 2018. (Short Communication).

CUNHA, L.T.M.; LEONCIONI, E.A.; GONÇALVEZ, C. et al. Influence of stocking density on weight gain and behavior of feedlot lambs. Small Ruminant Res., v.115, p.1-6, 2013.

EKEOCHA, A.H.; FAKOLADE, P.O. Effect of graded levels of Mexican sunflower leaf (Tithonia diversifolia Hemsl. A. gray) meal on the feed intake of ewe during the entire gestation period of 150 days. Sci. J. Anim. Sci., v.1, p.107-118, 2012.

ELLISON, M.J.; CONANT, G.C.; LAMBERSON, W.R. et al. Diet and feed efficiency status affect rumen microbial profiles of sheep. Small Ruminant Res., v.156, p.12-19, 2017.

ESPINOSA-GARCÍA, J.A.; QUIROZVALIENTE J.; MOCTEZUMA-LÓPEZ, G. et al. Berumen-Alatorre. Prospección tecnológica y estrategias de innovación para producción ovina en Tabasco, México. Rev. Cient., FCV-LUZ, v.25, p.107-115, 2015.

FASUYI, A.O.; IBITAYO, F.J. Preliminary analyses and amino acid profile of wild sunflower (Tithonia diversifolia) leaves. Int. J. Biol. Chem. Sci., v.5, p.164-170, 2011.

FORBES, J.M. A personal view ofhow ruminant animals control their intake and choice of food: minimal total discomfort. Nutr. Res. Rev., v.20, p.132-146, 2007.
GALLEGO-CASTRO, L.A.; MAHECHALEDESMA L.; ANGULO-ARIZALA, J. Calidad nutricional de Tithonia diversifolia helms A. gray. Bajo tres sistemas de siembra en el trópico alto. Agron. Mesoam., v.28, p.213-222, 2017.

GARCÍA, E. Modificaciones al sistema de clasificación climática de Koppen. 4.ed. México: Universidad Nacional Autónoma de México, 2004. 217p.

GONZÁLEZ-CASTILLO, J.C.; HAHN VONHESSBERG, C.M.; NARVÁEZ-SOLARTE W. Características botánicas de Tithonia diversifolia (Asterales: Asteraceae) y su uso en la alimentación animal. Bol. Cient. Mus. Hist. Nat., v.18, p.45-58, 2014.

GUTIÉRREZ, D.; MORALES, A.; ELÍAS, A. et al. Chemical composition and in situ ruminal degradability of dry matter in mixed silages of Tithonia diversifolia: Pennisetum purpureum cv. Cuba CT-169, inoculated with VITAFERT. Cuban J. Agric. Sci., v.48, p.379-385, 2014.

HERNÁNDEZ-MARÍN, J.A.; VALENCIAPOSADAS, M.; RUÍZ-NIETO, J.E. et al. Contribución de la ovinocultura al sector pecuario en México. Agro Prod., v.10, p.87-93, 2017.

INEGI. Prontuario de información geográfica municipal de los Estados Unidos mexicanos. Puebla. 2009. (Clave geoestadística 21076).

LA, O.; GONZÁLEZ, H.; OROZCO, A. et al. Composición química, degradabilidad ruminal in situ y digestibilidad in vitro de eco tipos de Tithonia diversifolia de interés para la alimentación de rumiantes. Rev. Cub. Cienc. Agríc., v.46, p.47-53, 2012.

LEZCANO, Y.; SOCA, M.; OJEDA, F. et al. Caracterización bromatológica de Tithonia diversifolia (Hemsl.) Agray en dos etapas de su ciclo fisiológico. Pastos Forrajes, v.35, p.275282, 2012.

MA, T.; WAN, F.; YANG, D. et al. Growth performance, nutrient digestibility, and slaughter traits ofmale fattening lambs under different feeding standards. Anim. Nutr., v.5, p.74-79, 2019. 
MEZA, G.A.; LOOR, N.J.; SÁNCHEZ, A.R. et al. Inclusión de harinas de follajes arbóreos y arbustivas tropical es Morus alba, Erythrina poeppigiana, Tithonia diversifolia e hibiscus rosa-sinensis) en la alimentación de cuyes (Cavia porcellus Linnaeus). Rev. Fac. Med. Vet. Zootec., v.61, p.258-269, 2014.

NARANJO, J.F.; CUARTAS, C.A. Caracterización nutricional y de la cinética de degradación ruminal de algunos de los recursos forrajeros con potencial para la suplementación de rumiantes en el trópico alto de Colombia. CES Med. Vet. Zootec., v.6, p.9-19, 2011.

NIEVES， D.; TERÁN, O.; CRUZ, L. Digestibilidad de nutrientes en follaje de árnica (Tithonia diversifolia) en conejos de engorde. Trop. Subtrop. Agroecosyst., v.14, p.309-314, 2011.

ODEDIRE, J.A.; OLOIDI, F.F. Feeding wild sunflower (Tithonia Diversifolia hemsl., A. gray) to West African dwarf goats as a dry season forage supplement. World J. Agricult. Res., v.6, p.280-284, 2014.

RIHAWI, S.; IÑIGUEZ, L.; W.F.; KNAUS, W.F. Fattening performance of lambs of different Awassi genotypes, fed under cost-reducing diets and contrasting housing conditions. Small Ruminant Res., v.94, p.38-44, 2010.
RODRÍGUEZ, A.B.; BODAS, R.; PRIETO, N. Effect of sex and feeding system on feed intake, growth, and meat and carcass characteristics of fattening Assaf lambs. Livest. Sci., v.116, p.118125,2008

RUÍZ, T.E.; FEBLES, G.J.; GALINDO, J.L. et al. Tithonia diversifolia, sus posibilidades en sistemas ganaderos. Rev. Cub. Cienc. Agríc., v.48, p.79-82, 2014.

SAS. User's guide Statistics. Version 9.4 (TS1MO). Cary: SAS Institute Inc., 2012.

SORMUNEN-CRISTIAN, R. Effect of barley and oats on feed intake, live weightgain and some carcass characteristics of fattening lambs. Small Ruminant Res., v.109, p.22-27, 2013.

SOTO, C.; REINOSO, V. Suplementación proteica enganado de carne. Rev. Soc. Vet., v.42, p.27-34, 2007.

VÁZQUEZ-MENDOZA, P.; CASTELÁNORTEGA, O.A.; GARCÍA-MARTÍNEZ, A.; AVILÉS-NOVA, F. Uso de bloques nutricionales como complemento para ovinos en el trópico seco del altiplano central de México. Trop. Subtrop. Agroecosyst., v.15, p.87-96, 2012.

VERDECIA, D.M.; RAMÍREZ, J.L.; LEONARD, I. et al. Calidad de la Tithonia diversifolia en una zona del Valle del Cauto. Rev. Electrón. Vet., v.12, p.1-13, 2011. 